\title{
Analisis Sumber Dan Penggunaan Modal Kerja Pada PT. Blue Bird Tbk
}

\author{
Tesalonika Meilani Supit \\ Frendy A.O. Pelleng \\ Joula J. Rogahang \\ Jurusan Ilmu Administrasi, Program Studi Administrasi Bisnis \\ Fakultas Ilmu Sosial dan Politik. Universitas Sam Ratulangi \\ tesalonikasupit22@gmail.com
}

\begin{abstract}
The purpose of this study was to determine how the implementation of the analysis of sources and uses of working capital at PT. Blue Bird Tbk. The method used is descriptive method using a quantitative approach to the analysis of financial statements. Data and data source is the annual report data from PT. Blue Bird Tbk. The results showed that: (1) Their role of the sources and uses of working capital as a whole, showing the level of effectiveness and efficiency is maintained so the security of the banking financial turnaround can work well and do not affect workers at the PT. Blue Bird Tbk, (2) development of the use of working capital PT. Blue Bird Tbk from years 2016-2017 corresponding financial statement analysis had experienced an increase in which the total assets to net working capital ratio shows the change of $+8,8 \%$; Current Liabilities to net working capital ratio shows changes $+1 \%$ and working capital turnover ratio shows the change of $+6,9 \%$. Observing the development of resources and the use of working capital at PT. Blue Bird Tbk. Shows the rate of change increased (+), then it is suggested, that the company's ,management constantly review, evaluate and assess reports of capital sources and uses of working capital so that it can ensure the performance of company's service increasingly better in the future.
\end{abstract}

Keywords: Sources of Funds, Use of Funds, Working Capital

\section{Pendahuluan}

Seiring dengan berkembangnya dunia usaha pada saat ini, persaingan antar perusahaan baik kecil maupun perusahaan besar semakin ketat. Perusahaan harus mampu mengelola usahanya dengan baik agar mampu tetap bertahan dalam persaingan. Perusahaan yang kuat akan bertahan hidup sebaliknya perusahaan yang tidak mampu bersaing kemungkinan akan dilikuidasi atau mengalami kebangkrutan. Oleh karena itu, untuk dapat menghadapi perubahan yang terjadi, perusahaan tentu saja harus melaksanakan fungsi-fungsi manajemen yang ada dalam perusahaan, seperti meliputi perencanaan, pengorganisasian, dan pengendalian secara baik sehingga tujuan atau sasaran utama perusahaan dapat tercapai. Disamping itu pula perusahaan perlu melakukan pengelolaan modal dengan baik agar tersedia modal yang cukup dalam melaksanakan peningkatan kegiatan operasi perusahaan seperti menambah tenaga kerja, mesin dan lain-lain ataupun dalam perluasan usaha. 
Analisis sumber dan penggunaan modal kerja merupakan alat analisis keuangan yang sangat penting bagi perusahaan/ badan usaha. Dengan analisis sumber dan penggunaan modal kerja, akan dapat dideteksi bagaimana perusahaan mengelola atau menggunakan modal kerja yang dimilikinya sehingga perusahaan dapat menjalankan operasi usahanya dengan sebaik-baiknya. PT. Bluebird Tbk atau Blue Bird Group merupakan perusahaan transportasi asal indonesia. Yang fokusnya untuk menjual jasa kepada masyarakat lewat transportasi. Dengan fokus bisnis tersebut maka PT, Bluebird mempunyai peranan yang cukup penting dalam bidang transportasi di Indonesia dengan menyediakan jasa taxi.

Melihat peran pentingnya pemahaman tentang sumber dan penggunaan modal kerja dalam peningkatan kinerja perusahaan, serta melihat persaingan bisnis dalam bidang transportasi ini sangat sengit dengan adanya Grab Maka dari itu, dalam hal ini peneliti tertarik untuk menelusuri dalam penelitian ini tentang bagaimana implementasi analisis sumber dan penggunaan modal kerja pada PT. Bluebird Tbk.

\section{Laporan Keuangan}

Dalam pengertian yang sederhana, laporan keuangan adalah: laporan yang menunjukkan kondisi keuangan perusahaan pada saat ini atau dalam suatu periode tertentu.

(Kasmir 2010). Laporan keuangan adalah merupakan pokok atau hasil akhir dari suatu proses akuntansi yang menjadi bahan informasi bagi para pemakainya sebagai salah satu bahan dalam proses pengambilan keputusan dan juga dapat menggambarkan indikator kesuksesan suatu perusahaan mencapai tujuannya.

\section{Sumber Modal Kerja}

Pada umumnya sumber modal kerja suatu perusahaan dapat berasal dari:

1. Hasil operasi perusahaan adalah jumlah net income yang nampak laporan perhitungan rugi laba ditambah dengan depresiasi dan amortisasi, jumlah ini menunjukkan jumlah modal kerja yang berasal dari hasil operasi perusahaan.

2. Keuntungan dari penjualan surat-surat berharga (investasi jangka pendek)

3. Penjualan aktiva tidak lancar.

\section{Fungsi Modal Kerja}

Peranan modal kerja bagi perusahaan adalah melindungi perusahaan terhadap krisis modal kerja karena turunnya nilai dari aktiva lancar, memungkinkan untuk dapat membayar kewajiban-kewajiban tepat pada waktunya, menjamin dimilikinya kredit standing perusahaan semakin besar 
dan memungkinkan perusahaan untuk menghadapi bahaya atau kesulitan keuangan yang terjadi, memungkinkan untuk memiliki persediaan dalam jumlah yang cukup dalam melayani konsumen, memungkinkan bagi perusahaan untuk dapat beroperasi yang lebih efisien karena tidak ada kesulitan untuk memperoleh barang atau jasa yang dibutuhkan, dan memungkinkan bagi perusahaan untuk memberikan syarat kredit yang lebih menguntungkan bagi pelanggan (Djarwanto, 2012: 116-117).

\section{Pentingnya Modal Kerja}

Ada beberapa alasan yang mendasari pentingnya pengelolaan modal kerja, yaitu: (Martono dan Agus H, 2011: 74)

1. Aktiva lancar dari perusahaan baik perusahaan manufaktur maupun perusahaan jasa memiliki jumlah yang cukup besar dibandingkan dengan jumlah aktiva secara keseluruhan.

2. Untuk perusahaan kecil, hutang jangka pendek merupakan sumber utama bagi pendanaan eksternal. Perusahaan ini tidak memiliki akses pada pasar modal untuk pendanaan jangka panjangnya.

3. Manajer keuangan dan anggotanya perlu memberikan porsi waktu yang sesuai untuk pengelolaan tentang halhal yang berkaitan dengan modal kerja.

\section{Metode Penelitian}

Penelitian ini berlokasi di perusahaan PT. Bluebird Tbk. Perusahaan ini merupakan perusahaan yang menjual jasa transportasi di Indonesia. Pemilihan lokasi didasarkan pada pertimbangan sebagai berikut :

Data yang diperoleh adalah dalam bentuk yang sudah jadi, yang berasal dari laporan keuangan perusahaan dalam kurun waktu 2 periode dan data tersebut berupa: neraca, laba rugi dan sejarah singkat perusahaan.

Data ini berguna bagi pihak-pihak yang berkepentingan sebagai input untuk mengetahui persoalan-persoalan yang dihadapi, sebagai alternatif jawaban, atau solusi atau suatu persoalan yang dihadapi, dan sebagai alat untuk menjelaskan dan mengisi proses analisis yang sedang berlangsung. (Muhammad Teguh 2014: 11)

Dalam hal ini, jenis data yang digunakan dalam penelitian ini adalah jenis data kuantitatif dan sumber datanya adalah data sekunder. Data sekunder merupakan sumber data penelitian yang diperoleh peneliti secara tidak langsung atau melalui media perantara. Data sekunder pada umumnya dapat berupa bukti, catatan, atau laporan historis, majalah, artikel yang telah tersusun dalam arsip baik yang dipublikasikan dan yang tidak (Arfan Ikhsan 2014: 122) 
Agar diperoleh data-data yang dapat diuji kebenarannya, maka dalam penelitian ini, teknik pengumpulan data dan instrumen pengumpulan data yang digunakan oleh penulis adalah dokumentasi, dan studi pustaka, kajian literature. Teknik analisis data yang digunakan dalam penelitian ini yaitu: menganalisis data, menginterpretasikan data kemudian menarik kesimpulan.

\section{Hasil dan Pembahasan}

Berdasarkan hasil perhitungan, maka evaluasi dengan menggunakan rasio kecukupan modal kerja dapat dilihat dalam tabel tingkat likuiditas pada PT. Bluebird Tbk tahun 2016 dan tahun 2017 sebagai berikut : Rasio Total Aktiva terhadap modal kerja bersih tahun 2016 Rasio Total terhadap Modal Kerja bersih adalah sebesar $52,5 \%$, dan pada tahun 2017 adalah sebesar $61,2 \%$. Hal ini menandakan bahwa Rasio Total Aktiva terhadap modal kerja dijamin oleh aktiva lancar dan hutang lancar. Hal ini menggambarkan seberapa besar efektivitas PT. Blue Bird Tbk terhadap modal kerja.

Rasio Kewajiban Lancar terhadap modal kerja PT. Blue Bird Tbk pada tahun 2016 adalah sebesar 5,8\%, dan pada tahun 2017 sebesar 6,8\% . Rasio kewajiban lancar ini merupakan ekspresi alternatif dari current ratio. Bila current ratio rendah, rasio ini akan tinggi mengindikasikan likuiditas rendah. Bila rasio rendah, current ratio akan tinggi, mengindikasikan likuiditas tinggi,

Berdasarkan data di atas, diketahui bahwa kewajiban lancar pada tahun 2016 sampai dengan tahun 2017, terjadi peningkatan Hal ini berarti, current ratio rendah dan mengakibatkan rasio ini akan tinggi dan mengindikasikan tingkat likuiditas rendah. Ini berarti, pihak perusahaan berhasil melakukan penekanan terhadap kewajiban lancarnya untuk meningkatkan pendapatan perusahaan sehingga rasio kewajiban lancar PT. Blue Bird Tbk adalah stabil.

Rasio Perputaran Modal Kerja (Revenues to rent working capital ratio) mengukur aktivitas bisnis terhadap kelebihan aktiva lancar atas kewajiban lancar. Jika rasio perputaran modal kerja tinggi mengindikasikan likuiditas yang rendah untuk mendukung operasional, rasio yang rendah menunjukkan likuiditas tinggi. Dilihat dari trend di atas maka perputaran modal kerja terdapat kenaikan setiap tahunnya dari tahun 2016 ke tahun 2017. Peningkatan ini disebabkan karena modal kerja bersih mengalami peningkatan.

\section{Kesimpulan}

Berdasarkan penjelasan diatas, maka dapat disimpulkan bahwa : 
Jika pengelolaan sumber dan penggunaan modal kerjanya efektif dan efisien, maka akan mempengaruhi kualitas pelayanan dan perputaran uang yang dimiliki perusahaan dan semakin meningkatkan hasil yang baik bagi perusahaan.

Secara keseluruhan, tingkat efektivitas dan efisien Modal Kerja dan penggunaannya pada PT. Blue Bird Tbk sangat terjaga dan diketahui bahwa sumber modal kerja perusahaan berasal dari laba terus meningkat setiap tahunnya dan ditambah dengan beberapa sumber lainnya. Sedangkan penggunaan modal kerja digunakan untuk menunjang aktivitas operasi perusahaan.

Perkembangan penggunaan modal kerja PT. Blue Bird Tbk dari tahun 20162017 sesuai analisis laporan keuangan tenyata mengalami peningkatan dimana Total assets to net working capital ratio menunjukkan perubahan $+8,8 \%$; Current Liabilities to net working capital ratio menunjukkan perubahan $+1 \%$ dan Working Capital Turnover ratio menunjukan perubahan sebesaar $+6,9 \%$.

\section{Saran}

Adapun beberapa saran yang dapat disampaikan antara lain :

Mengamati perkembangan sumber dan penggunaan modal kerja pada PT.
Bluebird Tbk menunjukkan tingkat perubahan meningkat $(+)$, maka disarankan agar pihak manajemen bank senantiasa memeriksa, mengevaluasi dan mengkaji laporan sumber modal dan penggunaan modal kerja sehingga hal ini dapat menjamin kinerja pelayanan perbankan yang makin baik di masa mendatang.

PT. Blue Bird Tbk telah memiliki sumber dan penggunaan modal kerja yang baik. Sebagai salah satu perusahaan yang sangat familiar dengan masyarakat, sangat diharapkan agar kualitas pelayanan yang baik selama ini ditunjukkan selalu dipertahankan agar mendatangkan keuntungan bagi pihak perusahaan sendiri, tetapi juga bagi semua masyarakat yang dilayani.

Apabila terjadi kelebihan modal kerja, perusahaan dapat melakukan investasi, ataupun pembentukan dana tertentu untuk meng-efisiensi pengelolaan aktiva ataupun menghindari adanya dana yang menganggur.

\section{Daftar Pustaka}

Ikhsan, Arfan. 2014. Metodologi Penelitian Bisnis. Medan: Citapustaka,

Teguh, Muhammad. 2014. Metode Kuantitatif Untuk Analisis Ekonomi Bisnis. Jakarta:

Kasmir, 2010. Pengantar Manajemen Keuangan. Jakarta : Kencana. 
Jurnal Administrasi Bisnis

Vol. 9. No. 1, 2019

(p-ISSN 2338-9605; e-2655-206X)

Martono dan Agus H. 2011. Manajemen

Keuangan. Yogyakarta: Ekonosia

Djarwanto PS. 2012. Pokok-Pokok Analisa

Laporan Keuangan. Yogyakarta:

BPFE 